\title{
Pemodelan E-Health User Acceptance dengan Pendekatan Sosioteknikal (Studi Kasus: Antrean Online Rumah Sakit dan Puskesmas Di Surabaya)
}

\author{
Irham A. Ghafar dan Adithya Sudiarno \\ Departemen Teknik Industri, Fakultas Teknologi Idustri, Institut Teknologi Sepuluh Nopember (ITS) \\ e-mail: adithya_sudiarno@ie.its.ac.id
}

\begin{abstract}
Abstrak-Perkembangan Teknologi Informasi dan Komunikasi mendorong Pemerintah Kota Surabaya untuk memanfaatkannya dalam membuat sistem pendaftaran antrean online pada Rumah Sakit dan Puskesmas di Surabaya. Teknologi ini dimanfaatkan untuk mengatasi permasalahan waktu antre yang lama dan administrasi pada pendaftaran layanan Rumah Sakit dan Puskesmas yang kemudian disebut e-Health Surabaya. Hingga saat ini, masih banyak masyarakat yang belum memanfaatkan fasilitas ini sehingga target penggunaan fasilitas $\mathrm{e}$-Health masih belum terpenuhi. Oleh karena itu, penelitian ini dilakukan untuk mengetahui faktor-faktor yang memengaruhi penerimaan teknologi pendaftaran online $e$-Health Surabaya. Penelitian ini dilakukan dengan menggunakan pendekatan sosioteknikal berupa Technology Acceptance Model (TAM) dan Makro Ergonomi yang kemudian diolah dengan metode Structural Equational Modelling (SEM). Penelitian ini menggunakan 7 variabel laten dan 35 indikator. Hasil penelitian menunjukkan bahwa terdapat 6 variabel yang memengaruhi penerimaan teknologi e-Health Surabaya, yaitu Perceived Ease of Use, Perceived Usefulness, Attitude, Social Influence, Behavioral Intention, dan Actual Usage. Rekomendasi perbaikan yang diberikan untuk fasilitas pendaftaran online e-Health Surabaya adalah peningkatan sosialisasi kepada masyarakat, perbaikan antarmuka dan konten media layanan, serta penambahan Rumah Sakit yang terdaftar di dalam aplikasi.
\end{abstract}

Kata Kunci-E-Health, Ergonomi Makro, Sosioteknikal, Structural Equational Modelling, Techology Acceptance Model.

\section{PENDAHULUAN}

$\mathrm{P}$ ERKEMBANGAN teknologi di dunia kini semakin cepat, termasuk perkembangan teknologi di Indonesia. Perkembangan teknologi tersebut turut pula memengaruhi pola pelayanan yang dilakukan pemerintah untuk memenuhi kebutuhan pihak yang berkepentingan. Salah satu pelayanan dari pemerintah Indonesia yang sangat dibutuhkan, terutama oleh masyarakat, adalah pada bidang kesehatan. Layanan pada bidang kesehatan ini dilakukan melalui fasilitas dari pemerintah berupa Rumah Sakit (RS) dan Pusat Kesehatan Masyarakat (Puskesmas). Dalam hal ini, pelayanan yang dilakukan RS dan Puskesmas yang berada di dalam pengawasan Dinas Kesehatan, menjadi tolok ukur kualitas pelayanan pemerintah kepada masyarakat dalam bidang kesehatan.
Salah satu kota di Indonesia yang berperan aktif dalam meningkatkan pelayanan pemerintah kepada masyarakat adalah kota Surabaya. Pemerintah Kota Surabaya terus berkomitmen dalam melakukan inovasi dalam pelayanan yang diberikan, termasuk pelayanan dalam bidang kesehatan. Komitmen untuk terus meningkatkan kualitas pelayanan publik ini mendorong Pemerintah Kota Surabaya untuk memanfaatkan Teknologi Informasi dan Komunikasi (TIK) dalam menyampaikan pelayanan kepada masyarakat. Pelayanan ini termasuk pelayanan dalam bidang kesehatan. Pemanfaataan TIK dalam bidang kesehatan ini terwujud dalam program e-Health sejak tahun 2015. Program e-Health ini mencakup berbagai pemanfaatan TIK dalam proses pelayanan kesehatan, termasuk penggunaan TIK untuk melakukan pendaftaran antrean di RS dan Puskesmas. Pelayanan $e$-Health merupakan pemanfaatan aplikasi online untuk mempermudah masyarakat dalam mendaftar antrean di RS dan Puskesmas. Melalui layanan $e$-Health, pemohon antrean tidak perlu datang ke loket pelayanan, namun hanya melakukan pendaftaran di manapun yang memiliki koneksi internet, atau pada $e$-Kios yang tersedia di seluruh kantor Kelurahan, Kecamatan, dan Puskesmas Kota Surabaya. e-Kios ini adalah sebuah mesin yang berisi program pelayanan pemerintah secara online. Salah satu layanan yang ditawarkan adalah program pendaftaran pada RS dan Puskesmas (e-Health).

Program $e$-Health diharapkan dapat menjadi solusi bagi permasalahan jumlah antrean pasien pada setiap hari kerja. Sebelum diimplementasikannya program $e$-Health ini, masyarakat yang ingin mendapatkan jasa pelayanan kesehatan di RS dan Puskesmas harus mengantre dalam waktu yang cukup lama, bahkan harus mengantre sebelum dimulainya jam kerja. Dengan memanfaatkan fasilitas $e$-Health ini, masyarakat diharapkan untuk tidak perlu mengantre lama untuk mendapatkan nomor antrean, namun cukup terhubung ke internet dan mengakses aplikasi $e$-Health untuk mendaftar atau mendatangi $e$-Kios pada tempat yang telah menyediakan fasilitas tersebut. Setelah itu, para pendaftar hanya perlu datang ke lokasi sesuai waktu yang tertera pada aplikasi. Selain itu, program e-Health ini juga dapat mempermudah pihak RS dan Puskesmas dalam proses administrasi terkait dengan pelayanan kepada pasien sehingga proses pelayanan seperti konsultasi kesehatan langsung dan rujukan dari 
Puskesmas menuju RS menjadi lebih cepat dan mengurangi risiko hilangnya dokumen data pasien.

Walaupun program pendaftaran antrean pada RS dan Puskesmas ini memiliki banyak manfaat untuk meningkatkan efisiensi pendaftaran, masih banyak masyarakat yang lebih memilih untuk mendaftar secara manual. Menurut data dari Dinas Kesehatan Kota Surabaya, selama Tahun 2016, hanya $28 \%$ pendaftar yang melakukan pendaftaran secara online baik untuk RS maupun untuk Puskesmas di Surabaya[1]. Hal ini menunjukkan bahwa masih terdapat celah untuk perbaikan dalam aplikasi ini sehingga pada akhirnya akan semakin banyak masyarakat yang menggunakan fasilitas pendaftaran antrean secara online. Hal ini pada akhirnya dapat meningkatkan efisiensi waktu yang dibutuhkan untuk proses pendaftaran dan meminimalisir permasalahan yang terjadi pada pendaftaran secara manual, baik dari segi waktu maupun dari segi administrasi.

Untuk mengetahui permasalahan yang terjadi terkait penerimaan sebuah teknologi pada masyarakat, terdapat beberapa metode penyelesaian masalah yang dapat digunakan. Salah satu metode tersebut adalah Technology Acceptance Model (TAM). TAM dianggap dapat menjelaskan faktorfaktor yang memengaruhi penerimaan sebuah teknologi pada masyarakat, termasuk teknologi $e$-Health yang menjadi pembahasan kali ini [2]. TAM menjelaskan bahwa penerimaan terhadap sebuah teknologi dipengaruhi oleh perceived usefulness (persepsi mengenai kegunaan atau manfaat teknologi tersebut) dan perceived ease of use (persepsi mengenai kemudahan penggunaan teknologi tersebut). TAM berfokus pada pembahasan mengenai sikap dari penggunaan sebuah teknologi. Model ini akan menjelaskan tentang variabel-variabel yang memengaruhi penerimaan oleh pengguna teknologi tersebut. Selain pada aspek teknologi, terdapat aspek sosial yang memengaruhi tingkat penggunaan teknologi tersebut oleh masyarakat. Untuk mengatasi permasalahan pada aspek ini, digunakan pendekatan Ergonomi Makro. Kedua metode yang digunakan di dalam pendekatan ini akan dilakukan dengan meneliti faktor-faktor yang memengaruhi penerimaan sebuah teknologi pada aspek sosial dan teknologi. Setelah itu, faktor-faktor ini akan diolah kembali dengan menggunakan metode Structural Equational Modelling (SEM) untuk mengetahui hubungan dan pengaruh antara faktor-faktor tersebut. Selain itu, tingkat pengaruh atau kepentingan juga akan diteliti sehingga faktor-faktor ini kemudian dapat digunakan untuk penyelesaian permasalahan yang ada dari aspek sosial dan teknologi untuk penerimaan program e-Health di Surabaya oleh masyarakat. Berdasarkan hal-hal tersebut, penelitian ini hendak mengembangkan sebuah model untuk menjelaskan faktor-faktor yang menentukan penerimaan dan penggunaan fasilitas pendaftaran online $e$ Health di Surabaya. Setelah itu, faktor-faktor paling berpengaruh di dalam penerimaan program $e$-Health ini akan dijadikan dasar dalam memberikan rekomendasi untuk pengembangan program $e$-Health Surabaya ini.

\section{METODOLOGI PENELITIAN}

Penelitian ini menggunakan survei melalui kuesioner secara online dan cetak yang dilakukan selama bulan Mei dan Juni 2017. Data penelitian dikumpulkan melalui kuesioner online yang disebarkan melalui media sosial dan kuesioner cetak yang disebarkan pada Rumah Sakit, Puskesmas, dan masyarakat di Surabaya secara acak. Data yang terkumpul adalah 90 responden dari kuesioner online dan 110 responden dari kuesioner cetak. Penyebaran data dihentikan ketika telah terkumpul 200 data responden.

Kuesioner yang disebarkan terdiri dari beberapa jenis pertanyaan yang dikelompokkan ke dalam tujuh konstruk, yaitu Internet Dependencies (ID), Perceived Ease of Use (PEOU), Perceived Usefulness (PU), Attitude (A), Social Influence (SI), Behavioral Intention (BI), dan Actual Usage (AU). ID dan SI adalah variabel eksternal karena mereka berfungsi sebagai pemberi pengaruh variabel PU dan BI (konstruk utama TAM). Penambahan ID dan SI sebagai variabel eksternal berdasarkan karakteristik teknologi $e$-Health Surabaya. Variabel eksternal ini juga disertakan berdasarkan pendekatan Ergonomi Makro untuk menggambarkan faktor sosial yang dapat memengaruhi penerimaan sebuah teknologi. ID merepresentasikan tingkat keakraban dan ketergantungan terhadap Internet. Sedangkan SI merepresentasikan pengaruh lingkungan sosial terhadap keputusan untuk menggunakan sebuah teknologi. PEOU, PU, A, BI, dan AU merupakan konstruk dasar TAM yang diajukan oleh Davis 1993 [2]. Setiap konstruk memiliki indikator masing-masing. Terdapat total 35 indikator. Petunjuk dasar pada metode Structural Equational Modelling (SEM) adalah jumlah minimum responden harus sebanyak lima kali lipat jumlah total indikator [3].

Pengolahan data dan analisis dilaksanakan dalam dua fase, yaitu fase Measurement Model dan Structural Model. Metode yang digunakan pada fase Meassurement Model adalah Confirmatory Factor Analysis (CFA). Sedangkan pada fase Structural Model, digunakan metode Structural Equational Modelling (SEM). Fase pertama ditujukan untuk memastikan kesesuaian antara model dan data (model goodness of fit). Fase kedua merupakan fase utama pada penelitian ini, yaitu untuk menguji seluruh hipotesis yang diajukan oleh model. Pada penelitian ini, setiap hipotesis adalah jalur yang menggambarkan hubungan antara dua konstruk. Sebuah hipotesis dapat diterima jika terdapat hubungan yang kuat antara dua konstruk yang terhubung. Fase pengolahan data dilaksanakan dengan menggunakan perangkat lunak SEM Berbasis Kovarian yang disebut LISREL. LISREL merupakan perangkat lunak yang paling banyak digunakan untuk menyelesaikan persoalan CFA dan SEM.

\section{HASIL}

Setelah seluruh data terkumpul, terdapat 200 responden yang mengisi kuesioner, baik secara online maupun cetak. Dengan metode SEM dan berdasarkan jumlah konstruk yang terdapat di dalam model yang diajukan, jumlah minimal responden yang dibutuhkan adalah 175 (lima kali jumlah indikator). Oleh karena itu, jumlah responden yang 
dikumpulkan selama proses pengumpulan data telah cukup untuk di analisis. Mayoritas responden berada di dalam rentang umum 21 hingga 30 tahun, pendidikan terakhir SMA atau sederajat, bekerja sebagai karyawan swasta, dan menghabiskan lebih dari lima jam untuk mengakses Internet dalam sehari.

Seperti yang telah dijelaskan sebelumnya, fase pertama dari pengolahan data adalah Measuremet Model dengan metode CFA. Tabel 1 menunjukkan ringkasan hasil dan cut-off value untuk tiap indeks kelayakan.

Tabel 1.

Ringkasan Goodess of Fit

\begin{tabular}{cccc}
\hline \hline Goodness of Fit Index & Cut Off Value & Hasil Uji & Keterangan \\
\hline RMSEA & $\leq 0.08$ & 0.08 & Model Fit \\
NFI & $\geq 0.90$ & 0.97 & Model Fit \\
NNFI & $\geq 0.90$ & 0.98 & Model Fit \\
CFI & $\geq 0.90$ & 0.98 & Model Fit \\
IFI & $\geq 0.90$ & 0.98 & Model Fit \\
RFI & $\geq 0.90$ & 0.97 & Model Fit \\
\hline \hline
\end{tabular}

Berdasarkan perbandingan antara hasil dan cut-off value yang ditunjukkan oleh Tabel 1, dapat disimpulkan bahwa setiap indeks kelayakan telah terpenuhi. Dapat disimpulkan bahwa Measurement Model telah memenuhi goodness of fit. Oleh karena itu, pengolahan data dan analisis dapat dilanjutkan ke fase selanjutnya, yaitu fase Structural Model.

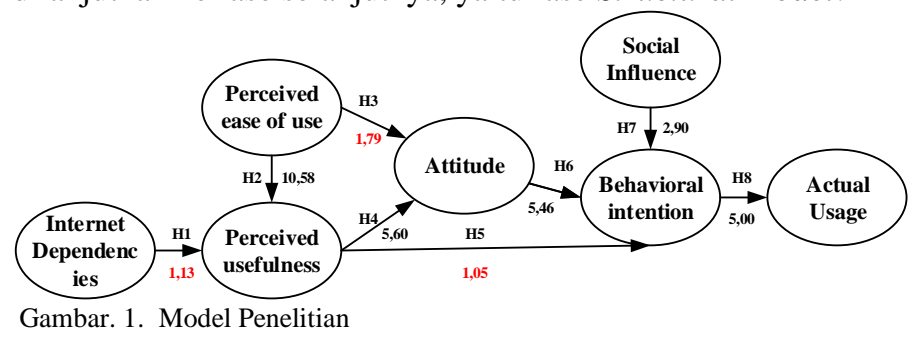

Model yang diajukan didalam penelitian ini dapat disebut "TAM yang dimodifikasi”. Gambar 1 menunjukkan TAM modifikasi dan hasil pengujian statistik dengan metode SEM. ID dan SI adalah variabel eksternal dari TAM orisinil yang diajukan oleh penelitian ini untuk meningkatkan kemampuan TAM untuk menjelaskan penerimaan pengguna berdasarkan pendekatan Ergonomi Makro. Berdasarkan hasil dari pengujian SEM sesuai Gambar 1, dapat diketahui bahwa terdapat tiga hipotesis yang ditolak, yaitu hipotesis 1, hipotesis 3 , dan hipotesis 5. Oleh karena itu, ketiga hubungan ini dihilangkan untuk mendapatkan model akhir yang diterima.

Berdasarkan Gambar 1, ditunjukkan bahwa Perceived Ease of Use (PEOU) memengaruhi Perceived Usefulness (PU) dan Perceived Usefulness (PU) memengaruhi Attitude (A). Sedangkan Attitude (A) dan Social Influence (SI) masingmasing memengaruhi Behavioral Intention (BI). Sedangkan Behavioral Intention (BI) memengaruhi Actual Usage (AU).

\section{DISKUSI DAN SIMPULAN}

Internet Dependencies (ID) dan Social Influence (SI) merepresentasikan faktor sosial yang memengaruhi penerimaan pengguna terhadap pendaftaran online e-Health Surabaya sebagai media untuk mendapatkan nomor antrean pada Rumah Sakit dan Puskesmas. ID adalah tingkat ketergantungan terhadap teknologi Internet. Sedangkan SI adalah pengaruh lingkungan sosial untuk menggunakan fasilitas $e$-Health Surabaya. Berdasarkan pengujian statistik yang ditunjukkan oleh Gambar 1, penerimaan teknologi $e$ Health Surabaya dipengaruhi oleh keberadaan SI.

Variabel eksternal ini adalah elemen penting yang terkait dengan aspek sosial yang akan meningkatkan penggunaan fasilitas $e$-Health Surabaya. Persepsi terhadap kemudahan dari penggunaan teknologi akan mendorong persepsi positif terhadap kegunaan dari teknologi e-Health. Persepsi terhadap kegunaan ini akan membuat pengguna memiliki perilaku positif disaat menggunakan teknologi e-Health Surabaya. Perilaku positif ini akan mendorong kesediaan pengguna yang menggambarkan harapan pengguna untuk menggunakan lagi fasilitas e-Health Surabaya pada masa yang akan datang. Kesediaan pengguna ini pun dipengaruhi oleh lingkungan sosial yang mendukung teknologi ini sehingga akan terwujud di dalam penggunaan fasilitas e-Health Surabaya yang sesungguhnya oleh masyarakat.

Pada penelitian ini yang fokus kepada karakteristik responden yang telah disebutkan sebelumnya. Karakteristik responden cenderung akrab dengan teknologi Internet namun banyak yang belum menggunakan fasilitas ini. Penyebab utama dari hal ini adalah ketidaktahuan terhadap fasilitas ini. Oleh karena itu, penelitian selanjutkan diharapkan akan lebih fokus untuk mengatasi permasalahan sosialisasi fasilitas pendaftaran online e-Health Surabaya.

\section{REKOMENDASI}

Dalam rangka untuk meningkatkan penggunaan fasilitas pendaftaran online e-Health Surabaya, terdapat beberapa rekomendasi yang perlu dipertimbangkan. Rekomendasi tersebut terdiri dari peningkatakn sosialisasi program, perbaikan antarmuka dan konten media layanan, dan penambahan jumlah Rumah Sakit di dalam daftar aplikasi. Peningkatan sosialisasi dilakukan untuk meningkatkan jumlah orang yang tahu program e-Health Surabaya ini sehingga meningkatkan Social Influence oleh masyarakat kepada sekitarnya. Perbaikan antarmuka dan konten media layanan dilakukan untuk meningkatkan Perceived Ease of Use oleh masyarakat sehingga mendorong Behavioral Intention untuk menggunakan fasilitas ini. Sedangkan Penambahan Rumah Sakit untuk meningkatkan Perceived Usefulness karena semakin banyak masyarakat yang dapat memnfaatkan fasilitas ini pada Rumah Sakit yang dituju. Kombinasi dari peningkatan ini pada akhirnya akan meningkatkan Actual Usage atau jumlah penggunaan fasilitas pendaftaran online e-Health Surabaya oleh masyarakat

\section{DAFTAR PUSTAKA}

[1] Anonim, "Laporan jumlah pengantre Rumah Sakit dan Puskesmas secara langsung dan online di Surabaya selama Tahun 2016," Surabaya, 2017.

[2] F. D. Davis, "User acceptance of information technology: system characteristics, user perceptions and behavioral impacts," Man- 
Machine Stud., vol. 38, pp. 475-487, 1993.

[3] T. R. Hair JF, Black WC, Babin BJ, Anderson RE, Multivariate data analysis. 6th ed. Prentice Hall, 2006. 